\title{
OBITUARY
}

\section{Barbara Anne Zolynski 16 June 1953 - 6 October 2015}

Barbara Zolynski had a very long and varied career. She started her working life as a teacher but later took a post graduate diploma in librarianship at the Polytechnic of North London and spent the first year of her new career at the British Library Map Room where she received a Society of College, National and University Libraries award.

A long period in academic libraries followed with jobs at the City of London Business School, the Polytechnic of Central London and the London School of Economics. In January 1990 Barbara took up the newly created post of European Communities Librarian at the Law Society. During her time at the Law Society Barbara contributed

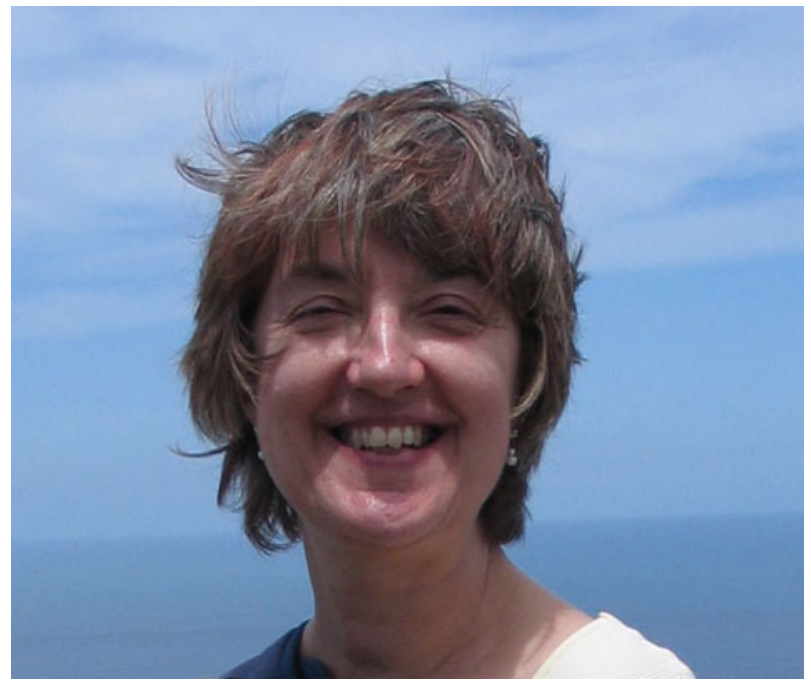

Figure I: Barbara Anne zolynski 1953-20I5. a huge amount to the European Community information world including writing two editions of the Basic Sources of European Communities Legislation in 1991 and 1996 and a chapter on EC Law in Dane and Thomas' How to Use $A$ Law Library. Barbara gained a diploma in EC law and lectured extensively on the subject. She also played a big role as events organiser and speaker for the European information Association.

In 1999, following a restructuring, Barbara left the Law Society and went to the College of Law for a brief period then the Inns of Court School of Law and, in 2004, Barbara moved to Herbert Smith, an international corporate law firm, as Head of Library and Information. For the next 10 years she saw to the information needs of well over 1000 lawyers and looked after a team of about 12 librarians. She was admired as a gifted librarian, a supportive and trustworthy manager and a woman of the highest calibre. As one of her colleagues said on hearing the news of her passing, 'It was impossible not to like and respect her'.

Her professional qualities were innumerable; she was remarkably clever, level-headed and organised, but she was also patient and generous. She was very funny and very, very kind and was loved by her team. All of those who worked with her feel lucky to have done so and their thoughts are succinctly expressed in the words of another of Barbara's Herbert Smith colleagues, 'Barbara was a beautiful and kind person. I will always remember her and all that I have learnt from her'.

Jane Webber (Legal Knowledge Co-ordinator, Herbert Smith Freehills) and Clare Costello (Library Assistant, Herbert Smith Freehills) 